\title{
Childhood Exposure to Air Pollution as a Potential Contributor of Chronic Non-Respiratory Inflammatory Disorders: A Longitudinal Prospective Cohort Study in Hamilton, Canada
}

\author{
Caroline Barakat-Haddad $^{1 *}$, Susan Elliott ${ }^{2}$, David Pengelly ${ }^{3}$ \\ ${ }^{1}$ Department of Anthropology, University of Toronto Scarborough, Toronto, Canada; ${ }^{2}$ Faculty of Applied Health Sciences, Univer- \\ sity of Waterloo, Waterloo, Canada; ${ }^{3}$ Department of Medicine, McMaster University, Hamilton, Canada. \\ Email: *cbarakat@utsc.utoronto.ca, elliotts@uwaterloo.ca, Pengelly@mcmaster.ca
}

Received May $13^{\text {th }}, 2013$; revised June $15^{\text {th }}, 2013$; accepted July $20^{\text {th }}, 2013$

Copyright (C) 2013 Caroline Barakat-Haddad et al. This is an open access article distributed under the Creative Commons Attribution License, which permits unrestricted use, distribution, and reproduction in any medium, provided the original work is properly cited.

\begin{abstract}
This study examines the relationship between childhood exposure to air pollution and diagnosis with chronic non-respiratory health outcomes in adulthood. This prospective cohort study uses data collected in the 1970/1980s from 395 children, including exposure to air pollution. Over thirty years later, a survey collected data on various health outcomes, including diagnosis with arthritis, high blood pressure, long-term skin conditions, and hay fever allergies. Logistic regression modeling was performed to examine the relative contribution of childhood exposure to air pollution on chronic non-respiratory health outcomes in adulthood. Childhood exposure to $\mathrm{SO}_{2}$ emerged as a significant predictor of arthritis $(\mathrm{OR}=2.73,95 \%$ CI 1.20 - 6.18) and high blood pressure $(\mathrm{OR}=2.82,95 \%$ CI 1.23 - 6.47). Other significant predictors include respiratory symptoms during childhood, family income during childhood and adulthood, property tenure, employment status, residential exposures, life events, physical activity, and body mass index. Childhood exposure to air pollution did not emerge as a significant predictor of long-term skin conditions or hay fever allergies. Findings contribute to the debate on the health effects of air pollution, indicating that the health impacts of childhood exposure to air pollution may include chronic inflammatory disorders in adulthood.
\end{abstract}

Keywords: Air Pollution; Health Development; Hay Fever; Arthritis; Hypertension; Skin Diseases

\section{Introduction}

Exposure to air pollution is detrimental to health. Literature documents increased risks of morbidity and mortality from exposure to acute episodes of air pollution [1]. For example, the London fog of 1952 led to an estimated 12,000 additional attributable deaths over a period of several months following the high levels of air pollution [1]. Policies adopted since the mid-twentieth century and largely driven by the environmental movement have reduced the levels of visible air pollutants [2]. While acute episodes of ambient air pollution have decreased, chronic exposures to relatively lower levels of air pollution are also implicated with negative health outcomes. Much of the air pollution and health research focuses on vulnerable sub-populations, who may be most impacted by

*Corresponding author. these exposures. Children are a sensitive sub-population due to their relatively smaller lungs, their stage of development and growth, and the proportion of time they spend outdoors [3]. In addition to physiological and behavioral features, children's relatively longer life expectancy provides an opportunity for certain latent conditions or diseases to manifest at some point along the life course. Cohort studies on children are considered the "gold standard" for assessing the long-term health impacts of exposure to ambient air pollution.

We undertook a systematic review of studies published between 1996 and 2006 on the relationship between childhood exposure to air pollution - particulate matter of any fraction size (PM), and sulphur dioxide $\left(\mathrm{SO}_{2}\right)$ and health, which revealed 5 review studies and 26 geographically based cohort studies. The follow-up period of these studies ranges between few weeks and 10 years, 
thus focusing on health measures in childhood. Studies reported associations between exposure to particulate matter of different sizes and bronchitis, lung function, and respiratory morbidity [4-8]. Literature suggests that PM2.5 have stronger acute respiratory impacts than coarse particles [9] and that PM2.5 are associated with decrements in lung function growth [10]. Significant associations were also found between childhood exposure to $\mathrm{SO}_{2}$ and respiratory symptoms (persistent wheeze, cough, phlegm), lifetime prevalence of diagnosed asthma, infectious airway diseases (such as pneumonia, bronchitis, chest colds, and tonsillitis), and a decrease in lung function [5,11-13].

While most findings suggest that childhood exposure to chronic air pollution impacts respiratory health, there is a gap in knowledge on its impacts (if any) on chronic non-respiratory health outcomes in adulthood. This is especially relevant given research evidence that ultrafine PM can penetrate the epithelium and vascular walls in the body and be transported via the circulatory system to other body organs, where it can lead to inflammatory events $[14,15]$. This may include the release of inflamematory mediators into the circulation, which stimulate the bone marrow to release leukocytes and platelets, the driving force of autoimmune diseases [16]. Ambient pollutants trigger the respiratory tract epithelium to produce and release inflammatory cytokines [17] and can also cause oxidative stress to other body cells leading to inflammation $[18,19]$. Indeed, studies report positive associations between PM exposures and brain markers of inflammation in mice [20] and canines [21]. Human studies suggest that exposure to air pollution is related to brain inflammation and Abeta42 accumulation [22]. Inhalation of fine and ultrafine particles may also be related to platelet activation, a contributory factor of blood coagulation reactions [23]. While many human studies have in the past examined the link between exposure to air pollution and non-respiratory health outcomes (such as mortality and heart disease), these studies tend to focus on the adult population and thus do not account for childhood exposures to air pollution. Given that studies provide compelling evidence that PM is linked to lung and systemic inflammation [24,25], the possible link between childhood exposure to ambient air pollution and inflammatory disorders has yet to be fully explored [26]. There is scarce evidence that childhood exposure to air pollution may be related to negative health impacts related to inflammation in children. For example, Kaplan et al. [27] found that exposures to $\mathrm{SO}_{2}$ and $\mathrm{NO}_{2}$ in childhood may increase the risk of early-onset ulcerative colitis and Crohn's disease. Iannuzzi et al. [28] found that exposure to air pollution is associated with early atherosclerotic markers in healthy children. Poursafa et al. [29] found a positive association between childhood exposure to PM10 and the expression of tissue factor (TF) in atherosclerotic lesions, a key initiator of coagulation and considered to have a pivotal role in atherothrombosis. When accounting for the possible role of genetic variations in TF, a follow-up study suggests that in spite of similar genetic background, exposure to air pollutants had an independent association with serum TF level [30]. Associations have also been reported between exposure to air pollution and neurodevelopment and neurobehavioral functions in both children and adults [31-33], and the prevalence of anemia in children [34]. More recently, a review on the link between air pollution and non-alcoholic fatty liver diseases (NAFLD) documents evidence that point to air pollutant-induced systemic proinflammatory and oxidative responses as a risk factor for NAFLD [35]. The review points to results of a population-based study of children that found independent associations between different markers of air pollutants (including PM10 and $\mathrm{SO}_{2}$ ) and plasma markers of inflammation, oxidative stress, and insulin resistance [36].

The main objective of this study is to examine whether childhood exposures to ambient air pollutants are predictors of adult non-respiratory health outcomes: mainly, arthritis, high blood pressure, long-term skin conditions, and hay fever or allergies.

\section{Methods}

This prospective cohort study uses as a foundation 30year old longitudinal exposure and health outcome data from a cohort of participants $(n=3202)$ who resided in 4 distinct neighborhoods in Hamilton Ontario between 1978 and 1986 (Figure 1). The selected geographically distinct neighborhoods exhibited a gradient in air pollution levels with the east lower neighborhood having the highest levels of air pollution compared to the other three neighborhoods. Participants were between 6 and 8 years old in 1978. Data on air pollutant levels- $-\mathrm{SO}_{2}$ and particulate matter-was collected using a network of 22 monitoring stations located throughout the City of Hamilton. At the time, the cut-off size for measuring exposure to fine particulate was not recognized, and fine particulate was measured using PM under $3.3 \mu \mathrm{m}$ in aerodynamic diameter (PM3.3). (The current cut-off is PM2.5). In 2006, all cohort members who were successfully located $(\mathrm{n}=929)$ were invited to participate in this study; $68 \%$ consented to participate $(\mathrm{n}=598)$. A survey was developed for this research and was approved by the McMaster University Research Ethics Board (MREB). Data from childhood was obtained from the original research, while data from adulthood was collected using the selfadministered survey. Follow-up postcards and telephone reminders were used to enhance response rates, resulting 


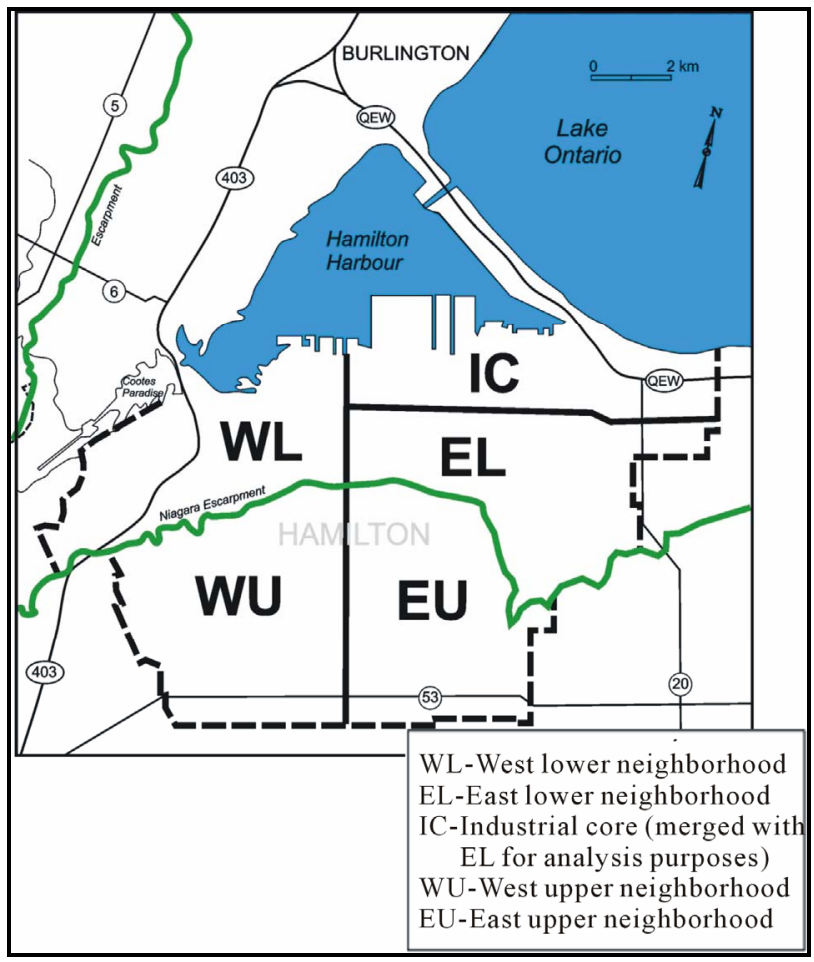

Figure 1. Map of the study area.

in a response rate of $66 \%$. Details of the original research program, research findings, cohort tracing, and results related to respiratory health outcomes have been published in this journal and elsewhere [37-42].

\subsection{Independent Variables from Childhood}

\subsubsection{Exposure Assessment}

Data on childhood exposure to air pollution included levels of SO2 in 1978/9 (mean age of participants $=8$ years); 1980/1 (mean age $=9$ years), 1981/2 (mean age $=$ 10 ), and $1983 / 4$ (mean age $=13$ years); TSP in $1980 / 1$, 1983/4, and 1985/6 (mean age $=15$ years); and PM3.3 in 1980/1, 1981/2, 83/4, and 1985/6. There were four methods that derived variables related to childhood exposure to air pollution for inclusion in the analysis. First, given that each participant was assigned personal annual exposure values in childhood - to TSP and PM3.3 in $1980 / 1,1981 / 2,1983 / 4$, and 1985/6; and exposures to SO2 in 1978/9, 1980/1, 1981/2, and 1983/4 - based on estimates derived from a response surface model [41], exposure to air pollution was retained as a continuous variable. In addition, exposure data were used to group participants into two categories based on whether they were exposed to specific air pollutants above the median level or at/below the median level for each sampling period (academic year) - a common method of evaluating exposures in air pollution epidemiology. The third method consisted of creating indices that indicate the frequency of exposure to TSP, $\mathrm{PM} 3.3$ and $\mathrm{SO}_{2}$ above or below the median level across all sampling periods. Lastly, participants were also categorized according to their residence in childhood into four geographic neighborhoods.

\subsubsection{Additional Independent Variables}

Other variables from childhood include exposure to second-hand smoking, household income (below the lowincome cut-off versus at or above the low income cutoff), dwelling type, smoking experience (one or more cigarettes per day for more than 6 months), age when smoking started, and asthma diagnosis. In order to examine the relative contribution of indoor air quality in childhood on long-term respiratory health, this environmental aspect was assessed using variables that measured exposure to indoor versus outdoor air including such as gas cooking. In addition, indices representing respiratory health in childhood were created for persistent morning cough, persistent day/night cough, persistent wheeze, chest colds or illnesses, and airway obstruction. The latter is assessed using the FEV1/FVC indicator (ratio of the forced expiratory volume in one second over the forced vital capacity) at or below the median. This measure was selected because it is intrinsically independent of body size [39].

\subsection{Independent Variables from Adulthood}

Independent variables from adulthood (mean age of participants $=36$ years) include data on the participant's macro-environment. This includes variables related to the residential environment, occupational history and exposures, socio-demographic variables, healthcare access, and life events. Data on the participant's microenvironment relates to behavioral (smoking, alcohol consumption, and physical activity), psychological (concern over air pollution; emotional distress; and feelings about income, health, and life) [43], and physiological variables (body mass index). Barakat-Haddad et al. (2012) [37] includes a detailed description of collected and derived variables from adulthood that are included in this analysis.

\subsection{Health Outcome Data}

Non-respiratory health outcomes were measured using 6 questions that asked whether participants were ever diagnosed with hay fever or environmental allergies, arthritis or rheumatism, high blood pressure or hypertension, any long-term skin conditions, any type of cancer, and any form of heart disease. Participants were also asked questions related to their respiratory health. Health measures are included as binary variables in the analysis. 


\subsection{Statistical Analyses}

Analysis was performed using the Statistical Package for the Social Science (SPSS-v12). A series of logistic regression modeling were run in order to examine the relative contribution of independent variables in predicting the occurrence of the following health outcomes: arthritis, hypertension, long-term skin conditions, hay fever or allergies, cancer, and heart disease. The method used in deriving these models is detailed in Barakat-Haddad et al. (2012) [37]. Results consist of two models for each health outcome one that includes significant predictors that explain the health outcome (best-fit model) and one that assesses the relative role of long-term exposure to air pollution on each health outcome, which is obtained by including the indices of long-term exposure to air pollution in the best fit models. The specificity and sensitivity of the models were noted.

\section{Results}

The prevalence of variables from the macro- and microenvironments are summarized in Table 1. The prevalence of the examined health outcomes is not significantly different across the four geographical neighborhoods (Table 2). In the first model, we examine diagnosis with arthritis or rheumatism. Results suggest that this health outcome is predicted by exposure to $\mathrm{SO}_{2}$ above the median level of $11.7 \mathrm{ppb}$ in 1983/84 (mean age of participants $=13$ years), experiencing two or more stressful life events, residential exposure to dust/gas/contaminants for a duration that exceeds 5 years, and being below the low-income cut-off in childhood (Table 3). Predictors of arthritis or rheumatism change when data are disaggregated by sex. The rho-square values for sex-specific models are greater than 0.2 indicating a good fit. However, the large range of confidence intervals for variables such as index for cough in childhood indicates uncertainty regarding the true effect of the explanatory variable. When variables related to long-term exposure to air pollution and neighborhood of residence in childhood are included in the best-fit model for arthritis or rheumatism, exposure to $\mathrm{SO}_{2}$ above 11.7 ppb in 1983/84 is no longer a statistically significant predictor of diagnosis with arthritis or rheumatism (Table 4). Surprisingly, results suggest that long-term exposure to PM3.3 decreases the odds of arthritis/rheumatism for females.

Results suggest that diagnosis with high blood pressure or hypertension is predicted by exposure to $\mathrm{SO}_{2}$ above $11.7 \mathrm{ppb}$ in $1983 / 84$, property ownership, and a current family income below the low-income cut-off (Table 3). Although, gender-related analysis gives rise to different predictors, rho-square values of all models are below 0.2 indicating a low goodness of fit (Table 3). When vari- ables related to long-term exposure to air pollution and neighborhood of residence in childhood are forced into the best-fit model, exposure to $\mathrm{SO}_{2}$ above $11.7 \mathrm{ppb}$ in 1983/84 remains a significant predictor of diagnosis with high blood pressure/hypertension (Table 5). Possibly due to the fact that some of the evaluated non-respiratory health outcomes - such as cancer and heart disease-are more typically seen in older adult populations, this research did not have the ability to evaluate these health outcomes. Childhood exposure to air pollution did not emerge as a significant predictor of long-term skin conditions, hay fever or allergies.

\section{Discussion}

The purpose of this article was to contribute to our understanding of the relative contribution of childhood exposure to air pollution on adult non-respiratory health outcomes. A number of issues arise from results of the logistic regression models, which achieved a range of values related to goodness of fit (rho-square value between 0.11 and 0.22 ), indicating good to strong goodness of fit. While results suggest that location of residence in childhood is not a predictor of diagnosis with arthritis or high blood pressure, rho-square values increased in most cases and remained the same in a few cases, when the indices of air pollution and neighborhood of residence in childhood were added to the models. This suggests that there may be factors at the regional level that impact these heath outcomes and that were not captured in the analysis. Examples are factors that may be related to inequity in opportunities and resource distribution (air quality), such as the degree of community integration, and the effect of perceived areas on the self-esteem and morale of residents.

Second, results suggest that exposure to $\mathrm{SO}_{2}$ in 1983/1984 above $11.7 \mathrm{ppb}$ (when the mean age of participants was 13 years) may predict arthritis/rheumatism and high blood pressure/hypertension in adulthood. Moreover, while accounting for the role of long-term exposures to air pollution and area of residence, analysis suggests that exposure to $\mathrm{SO}_{2}$ above $11.7 \mathrm{ppb}$ is a predictor of diagnosis with high blood pressure hypertension. These findings deserve further investigation given research evidence that implicates air pollution with systemic inflammatory events $[16,18,19,22]$ and the possible onset or progression of inflammatory disorders [26], particularly early atherosclerotic markers in healthy children. [28] While evidence about biological mechanisms implicating air pollution with a range of body reactionssuch as platelet activation, oxidative stress, pro-inflammatory responses, expression of tissue factor, and insulin resistance $[14,15,17-19,23,26,29,30,35,36]$ - continues to 
Childhood Exposure to Air Pollution as a Potential Contributor of Chronic Non-Respiratory Inflammatory Disorders: A

Longitudinal Prospective Cohort Study in Hamilton, Canada

Table 1. Distribution of variables that are used in this study.

\begin{tabular}{|c|c|c|c|}
\hline Construct & Variables & Classification & $\%$ \\
\hline \multicolumn{4}{|c|}{ Data from childhood (1976-1986) } \\
\hline \multirow{5}{*}{ Exposure to air pollution } & $\operatorname{TSP}(1980 / 1,83 / 4,85 / 6)\left(\mu \mathrm{g} / \mathrm{m}^{3}\right)$ & $\begin{array}{c}\text { Range — annual averages } \\
\text { Medians }\end{array}$ & $\begin{array}{l}31-75 \\
51,50,46\end{array}$ \\
\hline & TSP index & Always $>$ median & 17 \\
\hline & $\mathrm{PM}_{3.3}(1980 / 1,81 / 2,83 / 4,85 / 6)\left(\mu \mathrm{g} / \mathrm{m}^{3}\right)$ & Range — annual averages & $34-69$ \\
\hline & $\mathrm{PM}_{3.3}$ index & Always $>$ median & 24 \\
\hline & $\begin{array}{c}\mathrm{SO}_{2}(1978 / 9,1980 / 1,81 / 2,83 / 4)(\mathrm{ppb}) \\
\mathrm{SO}_{2} \text { index }\end{array}$ & $\begin{array}{c}\text { Range - annual averages } \\
\text { Medians } \\
\text { Always }>\text { median }\end{array}$ & $\begin{array}{c}5.4-17.3 \\
6.8,10.6,9.7,11.7 \\
10\end{array}$ \\
\hline Residential history & $\begin{array}{l}\text { Exposure to smoking } \\
\text { Neighborhood of residence }\end{array}$ & $\begin{array}{l}\text { Exposed } \\
\text { WU, EU, WL, EL }\end{array}$ & $\begin{array}{c}55 \\
29,27,19,25\end{array}$ \\
\hline Demographic features & $\begin{array}{l}\text { Sex } \\
\text { Household income }\end{array}$ & $\begin{array}{c}\text { Male } \\
\text { Below low-income cut-off }\end{array}$ & $\begin{array}{l}49 \\
16\end{array}$ \\
\hline Behavioral & Smoking & $\geq 1$ per day for $>6$ months & 16 \\
\hline Physiological factors & $\begin{array}{c}\text { Asthma } \\
\text { Indices for persistent cough or wheeze } \\
\text { Chest colds/illness before age of } 2 \\
\mathrm{FEV}_{1} / \mathrm{FVC} \text { pulmonary index }\end{array}$ & $\begin{array}{c}\text { Asthmatic } \\
\text { Range } \\
\text { Bronchitis/pneumonia } \\
\text { Range }\end{array}$ & $\begin{array}{c}11 \\
0-1 \\
6 \\
>0-1\end{array}$ \\
\hline \multicolumn{4}{|c|}{ Data from adulthood (2006/2007) } \\
\hline Air quality & Exposure to smoking & Exposed & 44 \\
\hline Residential history & $\begin{array}{c}\text { Previous residences } \\
\text { Residential exposures to gas/dust/contaminants } \\
\text { Use of air conditioner, humidifier, filter } \\
\text { Type of heating } \\
\text { Air duct cleaning } \\
\text { Cooking method } \\
\text { Resided in property built before } 1950\end{array}$ & $\begin{array}{c}\text { Always in Hamilton } \\
\text { Ever } \\
\text { (greater than } 2,5,8 \text { years) } \\
\text { Always/almost always } \\
\text { Gas/oil } \\
\text { Rarely/do not remember } \\
\text { Gas } \\
>5 \text { years }\end{array}$ & $\begin{array}{l}60 \\
92 \\
65,57,46 \\
76,29,27 \\
96 \\
68 \\
38 \\
25\end{array}$ \\
\hline Occupational history & $\begin{array}{l}\text { Length of occupational exposures to } \\
\text { gas/dust/contaminants (months) }\end{array}$ & $\begin{array}{c}\text { Full-time } \\
\text { Clerical } \\
\text { Manual } \\
\text { Managerial } \\
\text { Professional } \\
\text { Ever } \\
\text { (greater than } 2,5,8 \text { years) }\end{array}$ & $\begin{array}{r}60 \\
11 \\
23 \\
14 \\
48 \\
92 \\
65,57,46\end{array}$ \\
\hline Healthcare system & Healthcare & Have family doctor, Private insurance & 92,70 \\
\hline Social environment & $\begin{array}{l}\text { Social contact scale } \\
\text { Group participation scale }\end{array}$ & $\begin{array}{l}\text { Score } \leq 5 \\
\text { Score } \leq 4\end{array}$ & $\begin{array}{l}12 \\
69\end{array}$ \\
\hline Family environment & Record of asthma/respiratory problems & At least one parent & 69 \\
\hline & Marital status & Married/common law & 74 \\
\hline Demographic features & $\begin{array}{c}\text { Education } \\
\text { Current family income } \\
\text { Ethnicity } \\
\text { Housing tenure }\end{array}$ & $\begin{array}{l}\text { Completed high school } \\
\text { Below low-income cut-off } \\
\text { Born in Canada } \\
\text { Property ownership }\end{array}$ & $\begin{array}{c}98 \\
5 \\
95 \\
85\end{array}$ \\
\hline Life events & Life events & 2 or more stressful events & 10 \\
\hline Behavioral factors & $\begin{array}{c}\text { Smoking } \\
\text { Alcohol } \\
\text { Physical exercise }\end{array}$ & $\begin{array}{l}\text { Current smoker; ever daily smoker } \\
\text { Regular consumption } \\
\geq 3 \text { per week, }>30 \text { minutes }\end{array}$ & $\begin{array}{c}21,34 \\
11 \\
49\end{array}$ \\
\hline Psychological factors & $\begin{array}{l}\text { Concern over air pollution } \\
\text { Emotional distress } \\
\text { Feelings about income, health, life }\end{array}$ & $\begin{array}{c}\text { Moderate/extreme } \\
\text { score } \geq 4 \text { on GHQ } \\
\text { Mostly dissatisfied/unhappy/terrible }\end{array}$ & $\begin{array}{r}54 \\
11 \\
13,7,3\end{array}$ \\
\hline Physiological factors & BMI & $\geq 25$ & 67 \\
\hline
\end{tabular}


Table 2. Prevalence of non-respiratory and respiratory medical diagnosis in the sample $(n=395)$.

\begin{tabular}{|c|c|c|c|c|c|c|}
\hline & Outcome (\%) & WU & EU & WL & EL & Total \\
\hline \multirow{6}{*}{ Non-respiratory } & Arthritis/rheumatism & 11 & 9 & 9 & 12 & 10 \\
\hline & High blood pressure/hypertension & 7 & 11 & 13 & 9 & 10 \\
\hline & Long-term skin conditions & 13 & 17 & 13 & 22 & 17 \\
\hline & Hay fever/allergies & 43 & 48 & 40 & 37 & 42 \\
\hline & Heart disease & 0 & 2 & 3 & 0 & 1 \\
\hline & Cancer & 0 & 1 & 1 & 3 & 1 \\
\hline \multirow{5}{*}{ Respiratory } & Respiratory problems & 3 & 7 & 3 & 5 & 5 \\
\hline & Asthma in adulthood & 16 & 10 & 11 & 15 & 13 \\
\hline & Chronic bronchitis & 3 & 8 & 5 & 7 & 6 \\
\hline & Chest conditions (pneumonia/lung infections) & 3 & 6 & 7 & 6 & 5 \\
\hline & $\begin{array}{l}\text { Hospital/ER visits for respiratory problems since leaving elementary } \\
\text { school }^{*}\end{array}$ & 2 & 11 & 9 & 15 & 9 \\
\hline
\end{tabular}

${ }^{*} \mathrm{p}<0.05$; WU—west upper; EU—east upper; WL—west lower; EL-east lower.

Table 3. Logistic regression models for arthritis and high blood pressure.

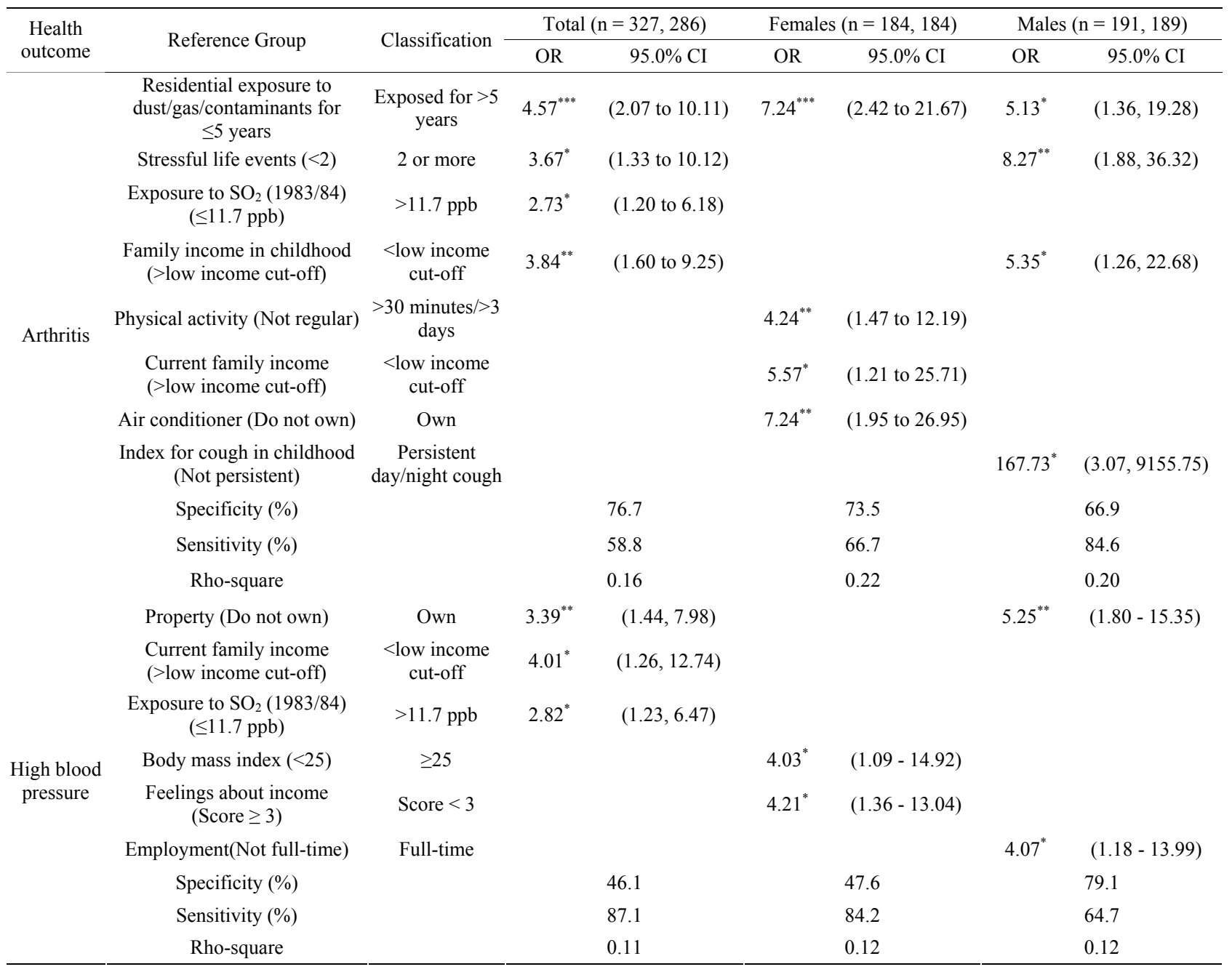

${ }^{*} \mathrm{p}<0.05 ;{ }^{* *} \mathrm{p}<0.01 ;{ }^{* * *} \mathrm{p}<0.001$. 
Longitudinal Prospective Cohort Study in Hamilton, Canada

Table 4. Long-term exposure to air pollution in childhood and diagnosis with arthritis.

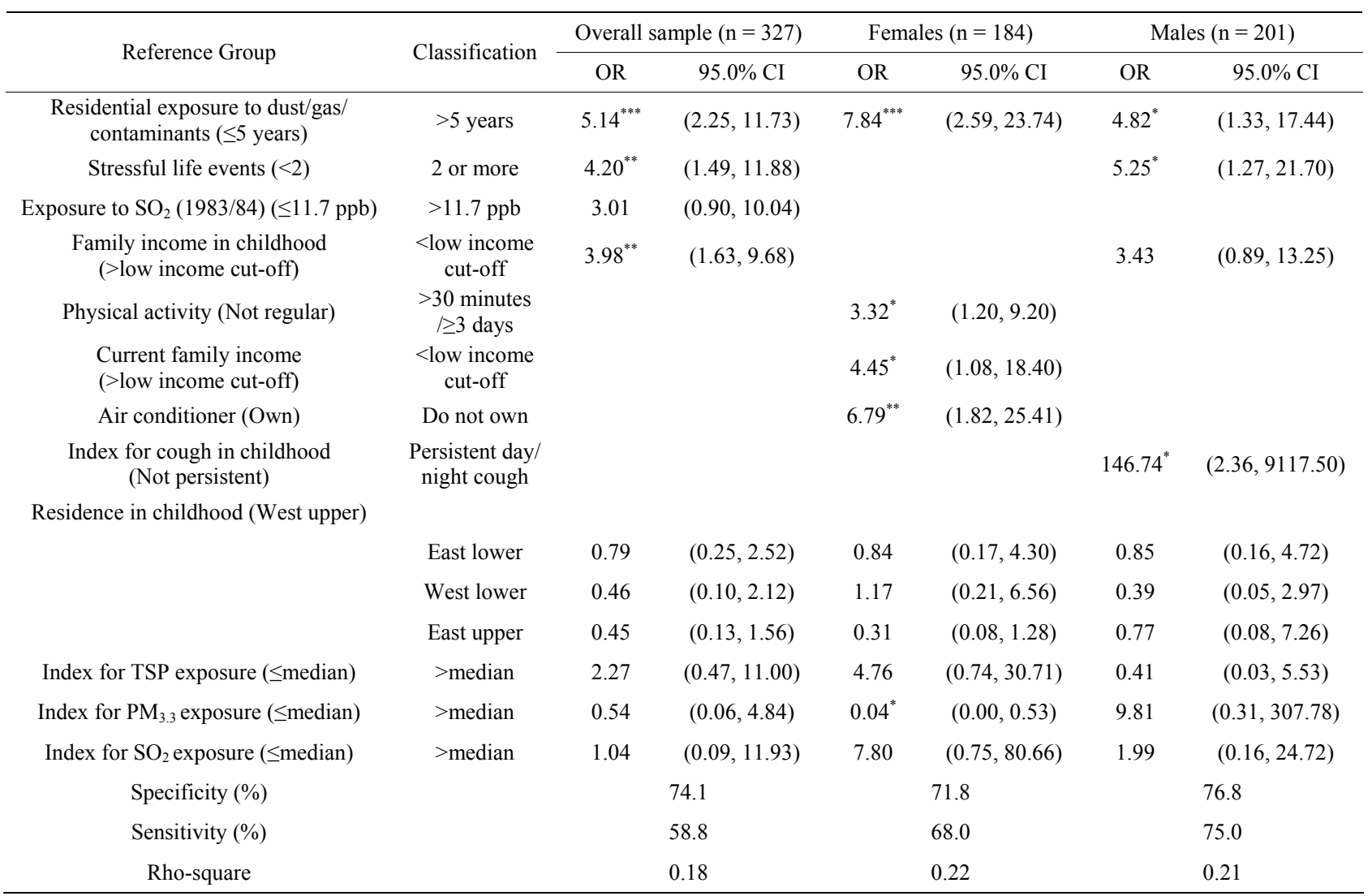

${ }^{*} \mathrm{p}<0.05 ;{ }^{* *} \mathrm{p}<0.01 ;{ }^{* * *} \mathrm{p}<0.001$

Table 5. Long-term exposure to air pollution in childhood and high blood pressure.

\begin{tabular}{|c|c|c|c|c|c|c|c|}
\hline \multirow{2}{*}{ Reference Group } & \multirow{2}{*}{ Classification } & \multicolumn{2}{|c|}{ Overall sample $(n=327)$} & \multicolumn{2}{|c|}{ Females $(n=184)$} & \multicolumn{2}{|c|}{ Males $(n=199)$} \\
\hline & & OR & $95.0 \% \mathrm{CI}$ & OR & $95.0 \% \mathrm{CI}$ & OR & $95.0 \% \mathrm{CI}$ \\
\hline Property ownership (Own) & Do not own & $3.52^{* *}$ & $(1.49,8.30)$ & & & $6.17^{* *}$ & $(2.01,18.89)$ \\
\hline $\begin{array}{l}\text { Current family income } \\
\text { (>low income cut-off) }\end{array}$ & $\begin{array}{c}<\text { low income } \\
\text { cut-off }\end{array}$ & $3.45^{*}$ & $(1.12,10.69)$ & & & & \\
\hline Exposure to $\mathrm{SO}_{2}(1983 / 84)(\leq 11.7 \mathrm{ppb})$ & $>11.7 \mathrm{ppb}$ & $4.24^{*}$ & $(1.19,15.09)$ & & & & \\
\hline Body mass index $(<25)$ & $\geq 25$ & & & $4.02^{*}$ & $(1.09,14.84)$ & & \\
\hline $\begin{array}{l}\text { Feelings about income } \\
\quad(\text { Score } \geq 3)\end{array}$ & Score $<3$ & & & $3.19^{*}$ & $(1.06,9.60)$ & & \\
\hline $\begin{array}{l}\text { Employment status } \\
\text { (Not full-time) }\end{array}$ & Full-time & & & & & 2.25 & $(0.64,7.95)$ \\
\hline \multicolumn{8}{|l|}{ Residence in childhood (West upper) } \\
\hline & East lower & 0.73 & $(0.20,2.70)$ & 1.42 & $(0.24,8.28)$ & 0.57 & $(0.11,3.06)$ \\
\hline & East upper & 1.30 & $(0.41,4.15)$ & 1.84 & $(0.40,8.54)$ & 0.75 & $(0.14,4.15)$ \\
\hline Index for TSP exposure ( $\leq$ median $)$ & $>$ median & 1.78 & $(0.41,7.66)$ & 1.58 & $(0.19,12.96)$ & 0.46 & $(0.06,3.40)$ \\
\hline Index for $\mathrm{PM}_{3.3}$ exposure ( $\leq$ median $)$ & $>$ median & 0.44 & $(0.05,3.62)$ & 0.43 & $(0.03,5.68)$ & 0.28 & $(0.02,5.15)$ \\
\hline Index for $\mathrm{SO}_{2}$ exposure $(\leq$ median $)$ & $>$ median & 0.31 & $(0.02,3.99)$ & 0.98 & $(0.11,8.92)$ & 2.73 & $(0.24,30.82)$ \\
\hline Specificity $(\%)$ & & \multicolumn{2}{|r|}{59.4} & \multicolumn{2}{|r|}{51.8} & \multicolumn{2}{|r|}{73.6} \\
\hline Sensitivity (\%) & & \multicolumn{2}{|r|}{87.9} & \multicolumn{2}{|r|}{71.4} & \multicolumn{2}{|r|}{70.6} \\
\hline Rho-square & & \multicolumn{2}{|r|}{0.12} & \multicolumn{2}{|r|}{0.12} & \multicolumn{2}{|r|}{0.12} \\
\hline
\end{tabular}

$\mathrm{p}<0.05 ;{ }^{* *} \mathrm{p}<0.01 ;{ }^{* * *} \mathrm{p}<0.001$. 
increase, there is a need for large scale longitudinal epidemiological studies that assess the impacts of early childhood exposure to diverse levels of air pollutants on non-respiratory inflammatory diseases in adulthood. Exposure to TSP and PM3.3 in 1980/1, 1981/2, 1983/4, and $1985 / 6$, and exposures to $\mathrm{SO}_{2}$ in 1978/9, 1980/1, and $1981 / 2$ did not predict any of the examined non-respiratory health outcomes. Surprisingly, results suggest that long-term exposure to PM3.3 decreases the odds of arthritis/rheumatism for females. These results may be attributed to the margin of error and deserve further investigation particularly given that the health impacts of exposure to PM are well supported by biological and epidemiological evidence.

Thirdly, other significant predictor variables of arthritis/rheumatism or high blood pressure/hypertension include residential exposures to gas/dust/contaminants, experiencing stressful life events, childhood family income, current family income, property ownership, employment status, adult body mass index, and persistent cough in childhood. Results suggest that residential exposures may be predictors of arthritis/rheumatism. It is understandable that diagnosis with arthritis/rheumatism may be associated with experiencing two or more stressful life events, given that such chronic conditions can have an impact on psychological and social health. In relation to physiological factors, persistent day/night cough in childhood predicts arthritis for males, whereas for females a body mass index greater or equal to 25 predicts high blood pressure. In terms of behavioral and psychological factors, significant predictors include regular physical activity and feelings about income. Results suggest that females who perform regular physical exercise, that are currently below the low-income cut-off, and that have an air conditioner have increased odds of diagnosis with arthritis/rheumatism. This is not surprising given that regular physical exercise and the use of air conditioner to keep the environment at a constant temperature are advisable treatments for people with arthritis or rheumatism.

This research was subject to certain limitations. First, the sole use of self-reported data limits findings due to the potential of differential recall bias, particularly in relation to residential and occupational exposures to dust or contaminants. Participants who are facing chronic health problems are more likely to recall and report past exposures than participants who are in good health. Second, the absence of data on exposure assessment to air pollution past childhood limited analysis on the health impacts of chronic exposure to air pollution across the life course, and prevented analysis on whether exposure to improved air quality has a reverse effect on health.
Thirdly, certain limitations are related to the absence of data from childhood such as participation levels in outdoor activities or time spent outdoors in childhood. Fourthly, the definition of the four geographical neighborhoods may have affected results of analysis of the role of location of residence in childhood on long-term health, particularly given that the east and west neighborhoods were divided arbitrarily. Finally, despite the fact that loss to follow-up is consistent with usual migration patterns, the possibility of selection bias still exists and is a limitation to this study. In addition, this research could have benefited from longitudinal physiologic measures that are capable of assessing various biological markers of inflammation, oxidative stress, and platelet activation.

\section{Acknowledgements}

We would like to thank Michelle Vine for her help in the data collection phase of this research.

\section{REFERENCES}

[1] M. L. Bell and D. L. Davis, "Reassessment of the Lethal London Fog of 1952: Novel Indicators of Acute and Chronic Consequences of Acute Exposure to Air Pollution," Environmental Health Perspectives, 109, Suppl. 3, 2001, pp. 389-394. doi:10.1289/ehp.01109s3389

[2] J. Neidell and Matthew, "Air Pollution, Health, and Socio-Economic Status: The Effect of Outdoor Air Quality on Childhood Asthma," Journal of Health Economics, Vol. 23, No. 6, 2004, pp. 1209-1236.

[3] J. Schwartz, “Air Pollution and Children's Health," Pediatrics, Vol. 113, No. 4, 2004, pp. 1037-1043.

[4] J. Gauderman, F. Gilliland, H. Vora, et al., "Association between Air Pollution and Lung Function Growth in Southern California Children. Results from a Second Cohort," American Journal of Respiratory and Critical Care Medicine, Vol. 166, No. 1, 2002, pp. 76-84. doi:10.1164/rcem.2111021

[5] J. Zhang, W. Hu, F. Wei, et al, "Children's Respiratory Morbidity Prevalence in Relation to Air Pollution in Four Chinese Cities," Environmental Health Perspectives, Vol. 110, No. 9, 2002, pp. 961-967. doi:10.1289/ehp.02110961

[6] D. W. Dockery, J. Cunningham, A. I. Damokosh, et al., "Health Effects of Acid Aerosols on North American Children: Respiratory Symptoms," Environmental Health Perspectives, Vol. 104, No. 5, 1996, pp. 500-505. doi:10.1289/ehp. 96104500

[7] M. Raizenne, M. Neas, I. Damokosh I, et al., "Health Effects of Acid Aerosols on North American Children: Pulmonary Function," Environmental Health Perspectives, Vol. 104, No. 5, 1996, pp. 506-551.

[8] D. Spengler, P. Koutrakis, W. Dockery, et al., "Health Effects of Acid Aerosols on North American Children: 
Air Pollution Exposures," Environmental Health Perspectives, Vol. 105, No. 5, 1996, pp. 492-499.

[9] J. Schwartz and N. Lucas, "Fine Particles Are More Strongly Associated than Coarse Particles with Acute Respiratory Health Effects in Schoolchildren," Epidemiology, Vol. 11, No. 1, 2000, pp. 6-10.

[10] D. Ward and J. Ayres, "Particulate Air Pollution and Panel Studies in Children: A Systematic Review," Occupational and Environmental Medicine, Vol. 61, No. 4, 2004, p. e13

[11] H. Pikhart, M. Bobak and P. Gorynski, "Outdoor Sulphur Dioxide and respiratory Symptoms in Czech and Polish School Children: A Small-Area Study (SAVIAH)," International Archives of Occupational and Environmental Health, Vol. 74, No. 8, 2001, pp. 574-578.

[12] A. Pinter, P. Rudnai, E. Sarkany, et al., "Air Pollution and Children's Respiratory Morbidity in the Tata Area, Hungary," Central European Journal of Public Health, Vol. 4S, 1996, pp. 17-20.

[13] J. Sanchez, I. Romieu, S. Ruiz, et al., "Efectos Agudos de las Particulasrespirables y del Dioxido de Azufresobre la Saludrespiratoria en Ninos del Area industrial de $\mathrm{Pu}-$ chuncavi, Chile," Revista Panamericana de Salud Pública, Vol. 6, No. 6, pp. 1999, 384-391.

[14] N. Künzli and I. B. Tager, "Air Pollution: From Lung to Heart," Swiss Medical Weekly, Vol. 135, No. 47-48, 2005, pp. 697-702.

[15] A. Blomberg, "Airway Inflammatory and Antioxidant Responses to Oxidative and Particulate Air PollutantsExperimental Exposure Studies in Humans," Clinical \& Experimental Allergy, Vol. 30, No. 3, 2000, pp. 310-317.

[16] S. F. Van Eden and J. C. Hogg, "Systemic Inflammatory Response Induced by Particulate Matter Air Pollution: The Importance of Bone-Marrow Stimulation," Journal of Toxicology and Environmental Health, Part A, Vol. 65, No. 20, 2002, pp. 1597-1613.

[17] A. Baeza-Squiban, V. Bonvallot, S. Boland, et al., "Airborne Particles Evoke an Inflammatory Response on Human Airway Epithelium. Activation of Transcription Factors," Cell Biology and Toxicology, Vol. 15, No. 6, 1999, pp. 375-380.

[18] W. MacNee and K. Donaldson, "Mechanism of Lung Injury Caused by PM10 and Ultra Fine Particles with Special Reference to COPD," European Respiratory Journal, Vol. 21, No. 47S-51S, 2003, p. S40.

[19] A. Zeka, J. R. Sullivan, P. S. Vokonas, et al., "Inflammatory Markers and Particulate Air Pollution: Characterizing the Pathway to Disease," International Journal of Epidemiology, Vol. 35, No. 5, 2006, pp. 1347-1354.

[20] A. Campbell, M. Oldham, A. Becaria, et al., "Particulate Matter in Polluted Air May Increase Biomarkers of Inflammation in Mouse Brain," Neurotoxicology, Vol. 26, No. 1, 2005, pp. 133-140.

[21] L. Calderon-Garciduenas, R. R. Maronpot, R. TorresJardon, et al., "DNA Damage in Nasal and Brain Tissues of Canines Exposed to Air Pollutants Is Associated with Evidence of Chronic Brain Inflammation and Neurode- generation," Toxicologic Pathology, Vol. 31, No. 5, 2003, pp. 524-538. doi:10.1080/01926230390226645

[22] L. Calderon-Garciduenas, W. Reed, R. R. Maronpot, et al., "Brain Inflammation and Alzheimer's-Like Pathology in Individuals Exposed to Severe Air Pollution," Toxicologic Pathology, Vol. 32, No. 6, 2004, pp. 650-658. doi: 10.1080/01926230490520232

[23] P. Poursafa and R. Kelishadi, "Air Pollution, Platelet Activation and Atherosclerosis," Inflammation \& AllergyDrug Targets, Vol. 9, No. 5, 2010, pp. 387-392. doi: $10.2174 / 187152810793937982$

[24] M. L. Scapellato and M. Lotti, "Short-Term Effects of Particulate Matter; an Inflammatory Mechanism?" Critical Reviews in Toxicology, Vol. 37, No. 6, 2007, pp. 461487.

[25] M. Lotti, I. Olivato and L. Bergamo, "Inflammation and Short-Term Cardiopulmonary Effects of Particulate Matter," Nanotoxicology, Vol. 3, No. 1, 2009, pp. 27-32. doi:10.1080/17435390802538763

[26] S. A. Ritz, "Air Pollution as a Potential Contributor to the 'Epidemic' of Autoimmune Disease," Medical Hypotheses, Vol. 74, No. 1, 2010, pp. 110-117. doi:10.1016/j.mehy.2009.07.033

[27] G. G. Kaplan, J. Hubbard, J. Korzenik, et al., "The Inflammatory Bowel Diseases and Ambient Air Pollution: A Novel Association," The American Journal of Gastroenterology, Vol. 105, No. 11, 2010, pp. 2412-2419.

[28] A. Iannuzzi, M. C. Verga, M. Renis, et al., "Air Pollution and Carotid Arterial Stiffness in Children," Cardiology in the Young, Vol. 20, No. 2, 2010, pp. 186-190.

[29] P. Pousafa, R. Kelishadi, A. Lahijansadeh, et al., "The Relationship of Air Pollution and Surrogate Markers of Endothelial Dysfunction in a Population-Based Sample of Children," BMC Public Health, Vol. 11, 2011, pp. 115122. doi:10.1186/1471-2458-11-115

[30] P. Poursafa, R. Kelishadi, F. Moattar, et al., "Genetic Variation in the Association of Air Pollutants with a Biomarker of Vascular Injury in Children and Adolescents in Isfahan, Iran," Journal of International Medical Research, Vol. 16, No. 6, 2011, pp. 733-740.

[31] C. Freire, R. Ramos, R. Puertas, et al., "Association of Traffic-Related Air Pollution with Cognitive Development in Children," Journal of Epidemiology \& Community Health, Vol. 64, No. 3, 2010, pp. 223-228. doi:10.1136/jech.2008.084574

[32] S. Q. Wang, J. L. Zhang, X. D. Zeng, et al., “Association of Traffic-Related Air Pollution with Children's Neurobehavioral Functions in Quanzhou, China," Environmental Health Perspectives, Vol. 117, No. 10, 2009, 1612-1618.

[33] J. C. Chen and J. Schwartz, "Neurobehavioral Effects of Ambient Air Pollution on Cognitive Performance in US Adults," Neurotoxicology, Vol. 30, No. 2, 2009, pp. 231239. doi:10.1016/i.neuro.2008.12.011

[34] M. Nikolic, A. Nikic and A. Stankovic, "Effects of Air Pollution on Red Blood Cells in Children," Polish Journal of Environmental Studies, Vol. 17, No. 2, 2008, pp. 
267-271.

[35] R Kelishadi and P Poursafa, "Obesity and Air Pollution: Global Risk Factors for Pediatric Non-Alcoholic Fatty Liver Disease," Hepatitis Monthly, Vol. 11, No. 10, 2011, pp. 794-802.

[36] R. Kelishadi, N. Mirghaffari, P. Poursafa and S. Gidding, "Lifestyle and Environmental Factors Associated with Inflammation, Oxidative Stress and Insulin Resistance in Children," Atherosclerosis, Vol. 203, No. 1, 2009, pp. 311-319. doi:10.1016/j.atherosclerosis.2008.06.022

[37] C. Barakat-Haddad, S. Elliott and D. Pengelly, "Health Impacts of Air Pollution: A Life Course Approach for Examining Predictors of Respiratory Health in Adulthood," Annals of Epidemiology, Vol. 22, No. 4, 2012, pp. 239-249. doi:10.1016/j.annepidem.2012.02.010

[38] C. Barakat-Haddad, S. Elliott and D. Pengelly, "Does Chronic Exposure to Air Pollution in Childhood Impact Long-Term Respiratory Health?" Professional Geographer, Vol. 64, No. 3, 2012, pp. 1-18. doi:10.1080/00330124.2011.609775

[39] A. Kerigan, C. Goldsmith and D. Pengelly, "A ThreeYear Cohort Study of the Role of Environmental Factors in the Respiratory Health of Children in Hamilton, Ontario," The American Review of Respiratory Disease, Vol. 133, No. 6, 1986, pp. 987-993.

[40] D. Pengelly, A. Kerigan and C. H. Goldsmith, "Sensitivity of Children with Asthma to Chronic Low-Level Sulphur Dioxide Exposure," Proceedings of the 8th World Clean Air Congress 1989, The Hague, 11-15 September 1989.

[41] D. Pengelly, C. H. Goldsmith, A. T. Kerigan, et al., "The Hamilton Study: Estimating Exposure to Ambient Suspended Particles," JAPCA, Vol. 37, No. 12, 1987, pp. 1421-1428. doi:10.1080/08940630.1987.10466337

[42] C. Barakat-Haddad, S. Elliott, J. Eyles, et al., "Predictors of Locating Children Participants in Epidemiological Studies 20 Years after Last Contact: Internet Resources Facilitating Longitudinal Research," European Journal of Epidemiology, Vol. 24, No. 8, 2009, pp. 397-405. doi:10.1007/s10654-009-9364-5

[43] C. A. Donald and J. E. Ware, "The Measurement of Social Support," Research in Community and Mental Health, Vol. 4, 1984, pp. 325-370. 